\title{
Development of Motion Learning Media and Energy Conservation Law Through Coaster Tracks Based on Logger Pro Analysis
}

\author{
A. Setiyani' ${ }^{1}$, W. H. Kristiyanto ${ }^{1}$, F. S. Rondonuwu2* \\ ${ }^{1}$ Program Studi Pendidikan Fisika, Fakultas Sains dan Matematika, \\ Universitas Kristen Satya Wacana, Indonesia \\ ${ }^{2}$ Program Studi Fisika, Fakultas Sains dan Matematika, Universitas Kristen Satya Wacana, Indonesia
}

Submitted: 9 September 2018. Revised: 15 December 2018. Accepted: 1 January 2019

\begin{abstract}
Research has been conducted to find out relation position and speed to time, for objects that glide on a magnetic foundation by applying the Research and Development method. Data retrieval is done by using video train motion recordings which are analyzed using Logger Pro. The results of the analysis are represented in the form of data and graphics. Based on the data analysis and fitting using the Logger Pro, the following values are obtained: $v_{\text {train }} 0.027 \mathrm{~m} / \mathrm{s}, a_{\text {train }} 0.034 \mathrm{~m} / \mathrm{s}^{2}$, average train velocity 0.02572 $\mathrm{m} / \mathrm{s}$ and average train acceleration $0.03662 \mathrm{~m} / \mathrm{s}^{2}$ with RMSE (Root Mean Square Error) value of $0.013 \mathrm{~m}$. The acceleration value obtained is very small and almost close to zero, so it can be said that objects that experience irregular straight motion. The graph representation of velocity over time shows an increase in speed that is not constant. This is because there is still friction between the train and the runway and friction between magnets along the track with friction forces 4,566 N. The value of kinetic energy, potential energy, and mechanical energy can be determined by using the results of Logger Pro analysis.
\end{abstract}

\section{ABSTRAK}

Telah dilakukan penelitian untuk mengetahui grafik keterkaitan posisi dan kecepatan terhadap waktu, untuk benda yang meluncur di atas landasan magnetik dengan menerapkan metode Research and Development. Pengambilan data dilakukan dengan menggunakan video rekaman gerak kereta yang dianalisis menggunakan Logger Pro. Hasil analisis direpresentasikan dalam bentuk data dan grafik. Berdasarkan analisis dan fitting data menggunakan Logger Pro diperoleh nilai sebagai berikut $v_{\text {kereta }} 0,027 \mathrm{~m} / \mathrm{s}, a_{\text {kereta }}$ $0,034 \mathrm{~m} / \mathrm{s}^{2}, v_{\text {rata-rata }}$ kereta $0,02572 \mathrm{~m} / \mathrm{s}$ dan $a_{\text {rata-rata }}$ kereta $0,03662 \mathrm{~m} / \mathrm{s}^{2}$ dengan nilai RMSE (Root Mean Square Eror) sebesar $0,013 \mathrm{~m}$. Nilai percepatan yang diperoleh sangat kecil dan hampir mendekati nol, sehingga dapat dikatakan bahwa benda mengalami gerak lurus beraturan. Representasi grafik kecepatan terhadap waktu memperlihatkan pertambahan kecepatan yang tidak konstan. Hal ini dikarenakan masih terdapat gesekan yang terjadi antara kereta dengan landasan maupun gesekan antar magnet di sepanjang lintasan dengan gaya gesek 4,566 N. Nilai energi kinetik, energi potensial, dan energi mekanik dapat ditentukan besarnya menggunakan data hasil analisis Logger Pro.

Keywords: Acceleration; Conservation Energy; Position; Velocity

\section{INTRODUCTION}

Some physics teachers still use the direct learning method. This causes students not to be interested in physics and considers physics as a difficult subject (Hussain, Azeem, \& Shakor, 2011).

Actually, physics is not only related to

*Correspondence Address:

Jl. Diponegoro 52-60 Salatiga, 50711, Indonesia

E-mail: ferdy.rondonuwu@staff.uksw.edu theory and concepts, but also closely related to experiments. Unfortunately, not all experimental tools are available for all physics material (Wicaksono, \& Rifai, 2013).

In everyday life we often encounter various motion phenomena, internal forces and energy changes. However not all motions, force and energy changes can be observed or imagined by students directly (Eager, Pendrill, \& Reistod, 2016). For example, frictionless motion that occurs on a roller coaster is difficult for 
students to imagine directly. So that teachers need creativity in developing educational teaching aids (Wicaksono, \& Rifai, 2013). Educational teaching aids are one of the means of communication between teachers and students in the learning process (Hake, 2007). Besides learning through direct experience can provide direct reinforcement of the basic concepts of physics that have been given by the teacher (Lawrence, \& Jacquelyn, 2009).

Along with the passage of technology representation and interactions of various physical quantities in a phenomenon can be presented in dynamic formats in the form of animations and simulations (Zacharia, \& Anderson, 2003). Therefore, to support this idea, Open Source Physics (OSP) which is a computer modeling tool can be used as an application that is suitable to be implemented to increase the exploitation power of students as student interactions at the application level in the learning circle.

Logger Pro software is one of the video analysis and modeling tools built by the OSP Java framework, this program is designed as a support the need for data accuracy in Physics education (Christian, Esquembre, \& Barbato, 2012). Various studies reported that the use of video tracker tracking analysis software turned out to provide convenience for students and teachers in understanding the concepts of kinematics and sharpening multimode representation skills in solving Physics problems (Halliday, Resnick, \& Walker, 2010).

Many physical phenomena related to the motion of objects in everyday life. Unfortunately, not all motion phenomena can be shown in the classroom, for example motion without friction on the roller coaster. The results of previous studies showed that using Roller Coaster in teaching Physics it turns out students more easily understand the concept of Newton's $2^{\text {nd }}$ Law for two and three dimensional motion, as well as the direction of force vector that works in Roller Coaster circles and increase students' interest in learning Physics (Pendrill, 2013). Based on these research results as well as the design of this study it is expected to help students understand the concepts of physics related to kinematics and energy changes in roller coaster.

\section{METHOD}

This research was conducted at the Science and Mathematics Faculty (e-system)
Research Center at Satya Wacana Christian University Salatiga, Indonesia. Data retrieval is done by using experimental methods and measurement directly. In this study an experiment was conducted using a train launched on a magnetic base. This was done to determine the exact position of the train that moves on a magnetic base and determine the type of motion of the train as in Figure 1.

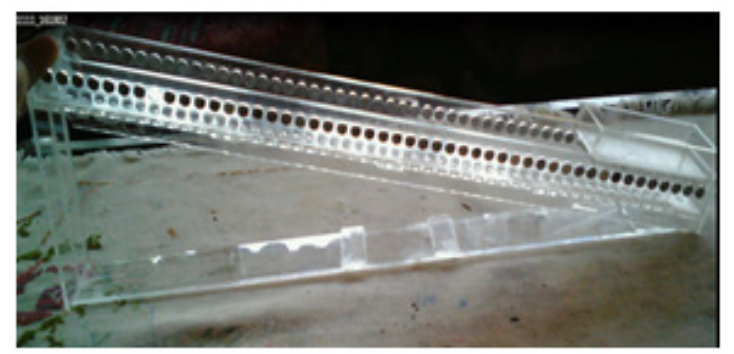

Figure 1. Design of magnetic platforms and trains

\section{Research Procedure}

Video capture of train motion is done by recording the motion of the train using a mobile camera. The video recordings are then inserted into a laptop that has been installed with Logger Pro application. The next step is setting the coordinate on the video by selecting the origin menu, and then moves the cursor on the video screen to form the $x-y$ coordinate point as shown in Figure 2.

Setting the frame rate to $34.72 \mathrm{fps}$ and determine the scale of motion of the video object by selecting the scale menu continues to enter the scale. By tracking each train movement that was launched, based on tracking, data of $x(m), y(m), v_{x}(m / s)$ and $v_{y}(m / s)$ were obtained. From the data provided, graphs s-t and v-t can be set.

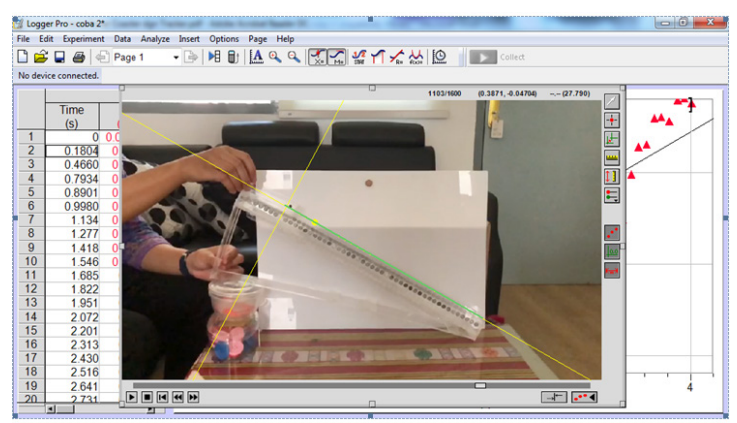

Figure 2. Video display along with its coordinate axis

\section{Data Analysis Procedure}

Based on the graph obtained the data 
analysis is carried out by selecting the analysis menu on the Logger Pro application toolbar and selecting curve fit followed by pressing the try fit button. From the results of the analysis carried out, it can be seen the equation of motion of the train launched. The video analysis data was stored at Microsoft Exel the calculate the position, velocity, acceleration, and energy contained in the train based on the results of the data fitting. After taking the recording, the video format changes to make it readable by the Logger Pro. Next, the software is applied to the train launched on a magnetic base. The results of tracking with the Logger Pro were shown in Figure 3.

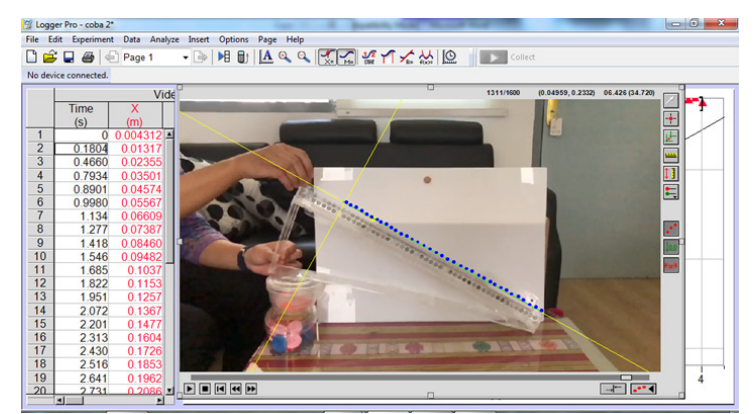

Figure 3. Results of tracking with Logger Pro application

\section{Tools and Materials}

The tools and materials used in this study include Neodymium magnets $0,8 \mathrm{~mm}$ in diameter, mobile phone camera, laptop, Logger Pro and Microsoft Excel applications.

\section{RESULTS AND DISCUSSION}

In various motion phenomena, to determine the position vector as a function of time can be explained from the relationship between position, velocity and time as indicated by equation (1), where $x$ is the final position $(m), x_{0}$ is the initial position $(\mathrm{m}), \mathrm{v}$ is the speed $(\mathrm{m} / \mathrm{s})$, and $\mathrm{t}$ is time (s) (Halliday, Resnick, \& Walker, 2010). $x=x_{0}+v t$

In most problems with fixed acceleration motion, we can formulate a position vector as a function of time as shown by equation 2 , where $\mathrm{v}_{0}$ is the initial velocity of the object $(\mathrm{m} / \mathrm{s})$, and is acceleration $\left(\mathrm{m} / \mathrm{s}^{2}\right)$ (Marshall, 2011).

$x=x_{0}+v_{0} t+\frac{1}{2} a t^{2}$

Equation (3) shows that there is a friction force, causing total mechanical force to be no longer constant, but changing as much as the effort carried out by friction force. In accordance with Newton's $2^{\text {nd }}$ Law equation, the acceleration of friction is equal to

$g \sin \theta-a=f_{g e s}$

Based on the results of tracking using the Logger Pro application, curve fitting is performed using a graph of the position and velocity related both to the upright axis (y-axis) and the horizontal axis (x-axis) toward time as shown in Figure 4.

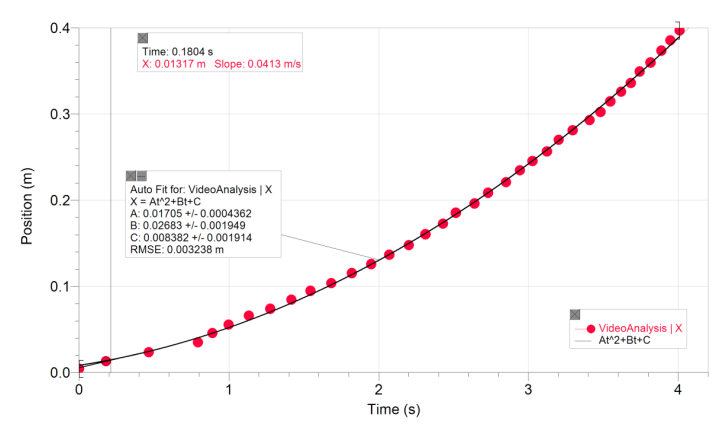

Figure 4. Results of fitting position (x) with time (t)

Based on the tracking data using the Logger Pro application, it is obtained graphical representation of the position's relation toward time as shown in Figure 4. The graphs obtained were analyzed using quadratic equations. In this case the system slope is $28^{\circ}$, and it is obtained train velocity $0.0413 \mathrm{~m} / \mathrm{s}$ with the value of RMSE (Root Mean Square Error) of 0.0032 $\mathrm{m}$. The slope of the graph shows the speed of the object. Based on the graph performance we can find out the position and speed of the train at each point. As in the second point, the train is at position $0.01317 \mathrm{~m}$ and with a speed of $0.0413 \mathrm{~m} / \mathrm{s}$. Besides the error value obtained is quite small, so it can be said that the analysis using quadratic equations is suitable for use in this study. In addition to the graphical representation of position with time, we can also represent a graph of velocity over time as shown in Figure 5.

The graph representation in Figure 5 shows that the speed of objects increases with time. Based on the graph of the results of the speed $(\mathrm{v})$ to time $(\mathrm{t})$ analysis, it is obtained that the average value of $0.02572 \mathrm{~m} / \mathrm{s}$ and system average is $0.03662 \mathrm{~m} / \mathrm{s}^{2}$ with the value of RMSE (Root Mean Square Error) of $0.013 \mathrm{~m}$. In this case the error value obtained is quite small, so it can be said that the analysis using 
linear equations is suitable to use even though the graph obtained is not smooth. This is because tracking is done manually and there are still external forces acting on this system such as friction caused by the train with the runway and friction between magnets along the track. In this study the value of friction force is quite large, which is $4.566 \mathrm{~N}$, so it can be said that the use of magnets on the track still cannot reduce friction to the maximum. Based on the graph that has been obtained, it can be used to determine the type of motion of the train. In this case it can be said that the train experiences Regular Changing Straight Motion with a speed that continues to increase with increasing time.

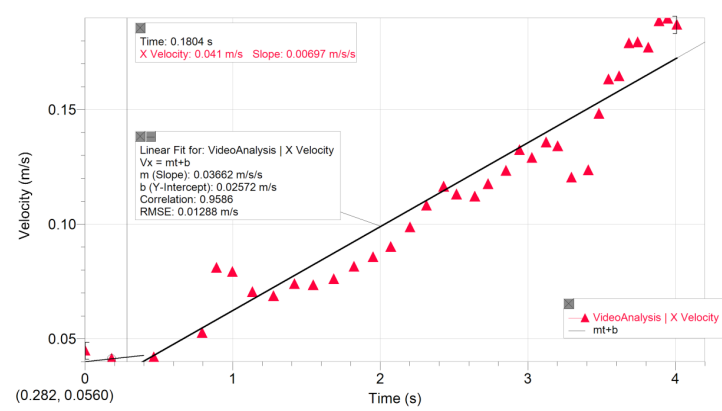

Figure 5. Results of the velocity (v) to time (t) fitting

When the train slides along the track, the potential energy on the train will be converted into kinetic energy. We need to know the amount of potential energy and kinetic energy to produce mechanical energy. This fact is known as the conservation law of mechanical energy as in equation (4), so it can be formulated

$$
\begin{aligned}
& E_{m 1}=E_{m 2} \\
& U_{1}+K_{1}=U_{2}+K_{2}
\end{aligned}
$$

Energy mechanics on the train is the amount of effort carried out by frictional forces, so we can pour mechanical energy again in the form

$\Delta K+\Delta U=W$

Based on the data analysis that has been done, at an altitude of $0.2285 \mathrm{~m}$. Mathematically, $\mathrm{Ep}_{\max } 1,29 \times 10^{-1} \mathrm{~J}$. is obtained while at the lowest point the train moves with $v 0,19$ $\mathrm{m} / \mathrm{s}$. Mathematically obtained $\mathrm{Ek}_{\max } 1,025 \times 10^{-3}$ J. The amount of potential energy and kinetic energy will produce mechanical energy. The magnitude of Ek objects is influenced by $v$ objects. The greater the $v$ of an object, the grea- ter the Ek achieved. While the magnitude of Ep objects is influenced by $h$, the greater the $h$ of an object, the greater the Ep, and vice versa. The amount of $\mathrm{Ep}_{\max }$ is the same as $\mathrm{Ek}_{\max }$ so that Em will be obtained which is always the same at each point and applies the Mechanical Energy Conservation Law (Halliday, Resnick, \& Walker, 2010). In this study different $\mathrm{Ep}_{\max }$ and $\mathrm{Ek}_{\max }$ were obtained. This can be because there are still external forces that influence the motion of the train, such as the friction that occurs between the train and the magnetic base and the friction caused by the magnets arranged along the track. Therefore, it can be said in this study that the Mechanical Energy Conservation Law does not apply. The magnitude of the object's mass can affect the mechanic energy of an object which then causes a decrease in acceleration in the object. This is due to the rough trajectory which results in the magnitude of the object's mass affecting the value of the friction force between two fields (Erlangga, \& Saputro, 2018).

\section{CONCLUSION}

Based on the data analysis and fitting using the Logger Pro application, the following value are obtained $v_{\text {train }} 0.027 \mathrm{~m} / \mathrm{s}$ and $a_{\text {train }}$ $0.034 \mathrm{~m} / \mathrm{s}^{2}$, average train velocity $0.02572 \mathrm{~m} / \mathrm{s}$ and average train acceleration $0.03662 \mathrm{~m} / \mathrm{s}^{2}$ with RMSE (Root Mean Square Error) value of $0.013 \mathrm{~m}$. However, the graph of the velocity obtained cannot be smooth. This is because the routing is done manually and there is still a friction force of $4,566 \mathrm{~N}$ in the system. Based on the graph obtained, it can be said that the train experiences Regular Changed Straight Motion with a speed that continues to increase with increasing time. Based on calculations obtained $\mathrm{Ep}$ at the highest point $0.2285 \mathrm{~m}$ amounting to $1.29 \times 10^{-1} \mathrm{~J}$. While at the lowest point the train moves with $\vee 0.19 \mathrm{~m} / \mathrm{s}$. Mathematically, the Ek is obtained at $1,025 \times 10^{-3} \mathrm{~J}$. In this study $\mathrm{Ep}_{\max }$ and $\mathrm{Ek}_{\max }$ were obtained differently. This can be occured because there are still external forces that influence the motion of the train, such as the friction that occurs between the train and the magnetic base and the friction caused by the magnets arranged along the track. Therefore it can be said in this study that the Mechanical Energy Conservation Law does not apply because the value of mechanical energy at each position is not equal. 


\section{REFERENCES}

Christian, W., Esquembre, F., \& Barbato, L. (2012). Tracker Video Analysis and Modelling Tool for Phsics Education. Open Source Physics Science. 334. 1077-1078. Retrieved from http://physlets.org/tracker/.

Eager, D., Pendrill, A. M., \& Reistod, N. (2016). Beyond Velocity and Acceleration, Jerk, Snap and Higher Denvative. European Journal of Physics. 37(6).1-11. https://doi. org/10.1088/0143-0807/37/6/065008.

Erlangga, S. Y., \& Saputro, H. (2018). Mini Roller Coaster (Miroco) Sebagai Media untuk Menghitung Percepatan Ditinjau dari Energi Mekanik. Risalah Fisika. 2(2). 29-33. Retrieved from http://journal.fisika.or.id/rf/article/ view/80/35

Hake, R. R. (2007). Design Based Research in Physics Education Research: A Review. Handbook of Design Research Methods in Mathematics Science and Technology Education. Retrieved from http://physics.indiana. edu.

Halliday, D., Resnick, R., \& Walker, J. (2010). Fundamentals of Physics ( $7^{\text {th }}$ ed). Jakarta: Erlangga.

Hussain, A., Azeem, M., \& Shakor, A. (2011). Physics Teaching Methods: Scientific Inquiry vs traditional Lecture. International Journal of Humanities and Social Science. 1(19). 269-276. Retrieved from https:// pdfs.semanticscholar.org/bab1/06e186d1 $5 a 6 b d 7 d b 5$ efaa6bf3adcee4d0053.pdf? ga $=2.183791141 .2041376358 .1558062207-$ 38394136.1558062207.

Lawrence, L. E., \& Jacquelyn, F. S. (1999). Handson Engineering: Learning by Doing in the Integrated Teaching and Learning Program. International Journal Engineering. 15(1). 2031. Retrieved from http://citeseerx.ist.psu. edu/viewdoc/download;jsessionid=4D7588E 163E9C8AEF694E1AD1DDCC50B?doi=10. 1.1.496.2168\&rep=rep1\&type=pdf.

Marshall, C. (2011). Roller Coaster Need Calculus Too. Undergraduate Journal of Mathematical Modelling: One + Two. 3(2). 5. Retrieved from https://scholarcommons.usf.edu/cgi/ viewcontent.cgi?referer=https://www.google. co. $. \mathrm{id} / \&$ httpsredir $=1 \&$ article $=4823 \&$ context $=u$ jmm.

Pendrill, A. M. (2013). Student Investigation of Forces in a Roller Coaster Loop. European Journal of Physics. 34(6). 1379-1389. https://doi. org/10.1088/0143-0807/34/6/1379.

Wicaksono, S., \& Rifai, N. I. (2013). Pembuatan Alat Peraga Pendidikan Fisika Sub Materi Gerak Jatuh Bebas Berbasis Mikrokontroler Arduino Uno. Prosiding Seminar Nasional Teknologi Terapan. Yogjakarta: Sekolah Vokasi UGM.

Zacharia, Z., \& Anderson, O. R. (2003). The Effects of an Interactive Computer Based Simulation Prior to Performing a Laboratory Inquiry Based Experiment on Student' Conceptual Understanding of Physics. American Journal of Physics. 71(6). 618-629. https://doi. org/10.1119/1.15664. 